\title{
Empirical Study of Cultural Educational Organizations' Accessibility to the Disabled People in the Regions of the Russian Federation
}

\author{
Alexander Volodin \\ Russian State Specialised Academy of Arts \\ Moscow, Russia \\ E-mail: voalan@mail.ru
}

\author{
Elena Blagireva \\ Russian State Specialised Academy of Arts \\ Moscow, Russia \\ E-mail: blagireva@list.ru
}

\begin{abstract}
This paper addresses the empirical study of the accessibility to the disabled people of educational organizations in the cultural sector in the constituent entities of the Russian Federation, including the description of steps, contents and conditions for carrying out such research. The latter assesses the accessibility to the disabled of different-level educational organizations in the regions of Russia by such statistical tools as the correlation and regression analysis, and the single-factor analysis of variance. These tools together provide for the identification of internal links and patterns of multilevel education for the people with disabilities and with special needs.
\end{abstract}

Keywords-research; education; culture; accessibility; disabled; people with special needs

\section{INTRODUCTION}

Today in Russia live around 13 million of the disabled people, accounting for approximately 8.8 percent of the populace, including 1283000 disabled people of the first group, 6250000 disabled people of the second group, 4601 000 disabled people of the third group, and 617000 disabled children. According to expert estimates, there are almost 190 000 hard of hearing people, about 320000 wheelchair-users and 240000 visually impaired people (from the interview with G.G. Lekarev, Russian Minister of Labour and Social Protection) [2]. The research shows that more than a third of all disabled people would like to engage in cultural activities, or $70 \%$ aged under 30 years and over $80 \%$ of the disabled aged 60 years and over [5].

According to the Information for general session of the Russian Ministry on the problems "Of accessibility of cultural goods to the disabled people", the Ministry and local cultural administrations in Russian regions have worked out and adopted regulations and requirements aimed at improving the accessibility of cultural goods and values to the Russians with disabilities [6].

In 2016, the Russian Ministry of culture had conducted monitoring of the accessibility of cultural goods to the people with disabilities and with special needs, the results of which are published on the Ministry's official website [7]. The monitoring was conducted in compliance with the Federal Law "On amendments to certain legislative acts of the Russian Federation on social protection of the disabled people relating to the ratification of the Convention on the Rights of Persons with Disabilities" No.419-FZ as of 01.12.2014 [8].

Analysis of the records of monitoring the accessibility of cultural goods to the disabled people encloses the so-called "dark" data and their analytical pre-processing. At the same time, in the provided monitoring records there is no assessment of cause-and-effect, statistical or other relationship in the field under study. The said enables to identify the emerged contradiction between the need to established trends in the cultural goods' accessibility to the disabled people, in accordance with regulatory requirements, and the lack of such an assessment.

Today there is an apparent objective need to implement in the continuous multilevel education system the qualimetric algorithms and technology that would allow for a better assessment of the feasibility of implementing educational programs and of the conformance of achieved results of training to the requirements of the community and employers, as well as to the professional personal expectations of graduates themselves. Availability of the multilevel education for the people with disabilities and special needs, on the one hand, correlates closely with different-level educational organizations in the cultural sector and, on the other hand, with several other factors. Analysis of the monitoring data on the accessibility of facilities and services in the regions of the Russian Federation showed that educational services in the cultural sector are rendered by 5103 art schools for children, 241 professional education organizations, 26 higher education organizations, supervised by local cultural administrating authorities [7].

To resolve the detected conflict the authors intend to assess the accessibility of different-level educational organizations in the cultural sector to the disabled people so to identify the trends in ensuring the multi-level education for people with disabilities and with special needs.

According to the hypothesis, proposed and tested by the authors of this study, if to identify the trends that feature the accessibility to the disabled people of different-level 
educational organizations in the cultural sector, this would allow to assess the availability of multi-level education for such people.

\section{THE EMPIRICAL RESEARCH METHODOLOGY}

The assessment of accessibility to the people with disabilities of different-level educational organizations working in the cultural sector in Russia's regions has applied the statistical techniques - the correlation-regression analysis and the single-factor analysis of variance [3] [4]. These tools together help identify intrinsic links and common factors of the availability of multi-level education for the people with disabilities and special needs.

Correlation is considered as the attribute that indicates the connectivity of a set of numerical sequences, it describes the data interconnection. The retrieval of correlative dependence helps determine probabilistic bonds between one variable $\mathrm{x}$ and another $-\mathrm{y}$. Consequently, the correlation analysis carries the inference on the bonding strength of a pair of findings $x$ and $y$. The more exact assessment of the extent of interconnection between the quantitative attributes can be obtained if to determine the measure of concordance of the resultant attribute's variation with the factorial attribute's variation. Closeness of the resultant $y$ and factor $x$ properties is measured by the linear correlation coefficient.

The regression analysis can reveal the analytical dependence that shows the dynamics of the resultant characteristic's mean value as effected by one or several independent variables. Many other factors that influence the resultant characteristic, however, are taken as permanent or average levels. Therefore, the regression analysis is indicative of how one value, for example, $y$, changes on average under corresponding changes in the other value $x$, and similarly, of how the variable $\mathrm{x}$ varies depending on the exponent $\mathrm{y}$.

On the one hand, the correlation-regression analysis allows the identification of the nature of statistical relationship of two or more accidental variables, and, on the other hand, the identification of mathematical expressions delineating the pattern of relationship between these accidental variables. The accessibility of higher education (regional and municipal universities), of secondary professional establishments and of children's art schools in Russian regions' cultural sector is presenting under our study accidental variables $-\mathrm{k}$.

The one-way analysis of variance (ANOVA) is applied to compare the mean values for three or more samples. A factor is identified as an independent variable the influence of which on the response variable is investigated. The investigation uses as the response variable the accessibility to the people with disabilities and with special needs of educational organizations and as the factor variable (independent variable) - the categories of educational organizations in Russia's regions. In our case, the factor (regional and municipal higher educational organizations, secondary professional establishments and art schools for children) comprises three independent one-dimensional samples - $\mathrm{k}$, whose entries are measured in alike units (pieces). In addition, the crucial prerequisite for ANOVA is fulfilled - the independent variable is categorical and the response variable is metric

"Table I" summarises the data available in the third volume of the document "The Accessibility status of cultural institutions and educational organizations. Results of monitoring the provision of conditions for accessibility of cultural goods to the persons with disabilities and with special needs in the Russian Federation" [7]. The paper is a part of the five-volume report on "Review of the results of monitoring conditions of the availability of cultural goods to the persons with disabilities and with special needs" [7].

TABLE I. ACCESSIBILITY OF EDUCATIONAL ORGANIZATIONS IN THE CULTURAL SECTOR IN REGIONS OF THE RF

\begin{tabular}{|c|c|c|c|c|}
\hline \multirow[b]{2}{*}{ No } & \multirow[b]{2}{*}{ Region } & \multicolumn{3}{|c|}{$\begin{array}{c}\text { Number of educational organizations } \\
\text { in the RF entities }\end{array}$} \\
\hline & & $\begin{array}{l}\text { Accessibility } \\
\text { of high } \\
\text { education in } \\
\text { cultural } \\
\text { sector } \\
\text { (regional and } \\
\text { municipal } \\
\text { universities) }\end{array}$ & $\begin{array}{c}\text { Accessibility } \\
\text { of } \\
\text { secondary } \\
\text { professional } \\
\text { organizatio } \\
\text { ns in } \\
\text { cultural } \\
\text { sector }\end{array}$ & $\begin{array}{c}\text { Accessibil } \\
\text { ity of art } \\
\text { schools } \\
\text { for } \\
\text { children } \\
\text { in } \\
\text { cultural } \\
\text { sector }\end{array}$ \\
\hline 1 & Altai Territory & 0 & 5 & 111 \\
\hline 2 & Amur Region & 0 & 1 & 34 \\
\hline 3 & Arkhangelsk Region & 0 & 2 & 39 \\
\hline 4 & Astrakhan Region & 1 & 3 & 26 \\
\hline 5 & Belgorod Region & 1 & 2 & 65 \\
\hline 6 & Bryansk Region & 0 & 0 & 53 \\
\hline 7 & Vladimir Region & 0 & 2 & 51 \\
\hline 8 & Volgograd Region & 1 & 1 & 82 \\
\hline 9 & Vologda Region & 0 & 3 & 44 \\
\hline 10 & Voronezh Region & 0 & 6 & 71 \\
\hline 11 & Moscow & 1 & 10 & 144 \\
\hline 12 & $\begin{array}{l}\text { Jewish Autonomous } \\
\text { Region }\end{array}$ & 0 & 1 & 9 \\
\hline 13 & Trans-Baikal Territory & 0 & 2 & 65 \\
\hline 14 & Ivanovo Region & 0 & 5 & 30 \\
\hline 15 & Irkutsk Region & 0 & 5 & 100 \\
\hline 16 & $\begin{array}{l}\text { Kabardino-Balkarian } \\
\text { Republic }\end{array}$ & 0 & 0 & 30 \\
\hline 17 & Kaliningrad Region & 0 & 1 & 40 \\
\hline 18 & Kaluga Region & 0 & 2 & 53 \\
\hline 19 & Kamchatka Territory & 0 & 1 & 31 \\
\hline 20 & $\begin{array}{l}\text { Karachayevo- } \\
\text { Cherkessian Republic }\end{array}$ & 0 & 1 & 28 \\
\hline 21 & Kemerovo Region & 1 & 5 & 122 \\
\hline 22 & Kirov Region & 0 & 3 & 74 \\
\hline 23 & Kostroma Region & 0 & 3 & 54 \\
\hline 24 & Krasnodar Territory & 0 & 6 & 180 \\
\hline 25 & Krasnoyarsk Territory & 0 & 6 & 126 \\
\hline 26 & Kurgan Region & 0 & 2 & 42 \\
\hline 27 & Kursk Region & 0 & 4 & 48 \\
\hline 28 & Leningrad Region & 0 & 1 & 66 \\
\hline 29 & Lipetsk Region & 0 & 2 & 37 \\
\hline 30 & Magadan Region & 0 & 1 & 14 \\
\hline 31 & Moscow Region & 0 & 4 & 217 \\
\hline 32 & Murmansk Region & 0 & 1 & 55 \\
\hline 33 & $\begin{array}{l}\text { Nenets } \\
\text { District }\end{array}$ & 0 & 3 & 2 \\
\hline 34 & $\begin{array}{l}\text { Nizhny } \quad \text { Novgorod } \\
\text { Region }\end{array}$ & 1 & 7 & 122 \\
\hline 35 & Novgorod Region & 0 & 1 & 32 \\
\hline 36 & Novosibirsk Region & 1 & 3 & 91 \\
\hline
\end{tabular}




\begin{tabular}{|c|c|c|c|c|}
\hline \multirow[b]{2}{*}{ No } & \multirow[b]{2}{*}{ Region } & \multicolumn{3}{|c|}{$\begin{array}{l}\text { Number of educational organizations } \\
\text { in the RF entities }\end{array}$} \\
\hline & & $\begin{array}{c}\text { Accessibility } \\
\text { of high } \\
\text { education in } \\
\text { cultural } \\
\text { sector } \\
\text { (regional and } \\
\text { municipal } \\
\text { universities) }\end{array}$ & $\begin{array}{c}\text { Accessibility } \\
\text { of } \\
\text { secondary } \\
\text { professional } \\
\text { organizatio } \\
\text { ns in } \\
\text { cultural } \\
\text { sector }\end{array}$ & $\begin{array}{c}\text { Accessibil } \\
\text { ity of art } \\
\text { schools } \\
\text { for } \\
\text { children } \\
\text { in } \\
\text { cultural } \\
\text { sector }\end{array}$ \\
\hline 37 & Omsk Region & 0 & 3 & 78 \\
\hline 38 & Orenburg Region & 1 & 4 & 64 \\
\hline 39 & Orel Region & 0 & 3 & 39 \\
\hline 40 & Penza Region & 0 & 3 & 50 \\
\hline 41 & Perm Territory & 0 & 5 & 100 \\
\hline 42 & Primorye Territory & 1 & 3 & 56 \\
\hline 43 & Pskov Region & 0 & 1 & 29 \\
\hline 44 & Republic of Adygeya & 0 & 1 & 21 \\
\hline 45 & Republic of Altai & 0 & 1 & 15 \\
\hline 46 & $\begin{array}{ll}\text { Republic } & \text { of } \\
\text { Bashkortostan }\end{array}$ & 0 & 8 & 129 \\
\hline 47 & Republic of Buryatia & 0 & 2 & 53 \\
\hline 48 & Republic of Dagestan & 0 & 4 & 93 \\
\hline 49 & Republic of Ingushetia & 0 & 1 & 8 \\
\hline 50 & Republic of Kalmykia & 0 & 1 & 17 \\
\hline 51 & Republic of Karelia & 0 & 2 & 32 \\
\hline 52 & Komi Republic & 0 & 3 & 43 \\
\hline 53 & Republic of Crimea & 2 & 3 & 67 \\
\hline 54 & Republic of Marij El & 0 & 2 & 46 \\
\hline 55 & Republic of Mordovia & 0 & 2 & 51 \\
\hline 56 & $\begin{array}{l}\begin{array}{l}\text { Republic of } \\
\text { (Yakutia) }\end{array} \\
\end{array}$ & 1 & 5 & 85 \\
\hline 57 & $\begin{array}{l}\text { Republic of } \\
\text { Ossetia-Alania }\end{array}$ & 0 & 3 & 24 \\
\hline 58 & Republic of Tatarstan & 2 & 9 & 104 \\
\hline 59 & Republic of Tuva & 0 & 1 & 31 \\
\hline 60 & Republic of Khakassia & 0 & 0 & 37 \\
\hline 61 & Rostov Region & 0 & 5 & 113 \\
\hline 62 & Ryazan Region & 0 & 0 & 0 \\
\hline 63 & Samara Region & 1 & 7 & 109 \\
\hline 64 & Saint-Petersburg & 0 & 7 & 57 \\
\hline 65 & Saratov Region & 0 & 2 & 93 \\
\hline 66 & Sakhalin Region & 1 & 1 & 34 \\
\hline 67 & Sverdlovsk Region & 1 & 9 & 161 \\
\hline 68 & Sebastopol & 0 & 0 & 9 \\
\hline 69 & Smolensk Region & 1 & 2 & 53 \\
\hline 70 & Stavropol Territory & 0 & 4 & 97 \\
\hline 71 & Tambov Region & 1 & 1 & 36 \\
\hline 72 & Tver Region & 0 & 3 & 64 \\
\hline 73 & Tomsk Region & 0 & 2 & 29 \\
\hline 74 & Tula Region & 0 & 3 & 37 \\
\hline 75 & Tyumen Region & 1 & 2 & 42 \\
\hline 76 & Republic of Udmurtia & 0 & 2 & 58 \\
\hline 77 & Ulyanovsk Region & 2 & 3 & 53 \\
\hline 78 & Khabarovsk Territory & 1 & 1 & 44 \\
\hline 79 & $\begin{array}{l}\text { Khanty-Mansijsk } \\
\text { Autonomous District - } \\
\text { Yugra }\end{array}$ & 0 & 3 & 58 \\
\hline 80 & Chelyabinsk Region & 2 & 2 & 130 \\
\hline 81 & Chechen Republic & 0 & 1 & 40 \\
\hline 82 & $\begin{array}{l}\text { Chuvash Republic - } \\
\text { Chuvashia }\end{array}$ & 1 & 3 & 46 \\
\hline 83 & $\begin{array}{l}\text { Chukotka Autonomous } \\
\text { District }\end{array}$ & 0 & 0 & 6 \\
\hline 84 & $\begin{array}{l}\text { Yamalo-Nenets } \\
\text { Autonomous District }\end{array}$ & 0 & 0 & 37 \\
\hline 85 & Yaroslavl Region & 0 & 3 & 37 \\
\hline $\mathrm{Nu}$ & ber of organizations & 26 & 241 & 5103 \\
\hline Ave & & 0.31 & 2.84 & 60.04 \\
\hline
\end{tabular}

The "Table I" data is going to serve as reference information for further investigation.

\section{EVALUATION}

Let us perform the necessary calculations consistent with the following steps:

- Construction of the complete correlation matrix and assessment of the variables' bond character;

- Construction of the regressions and identification of the mathematical expressions characterizing relationship between the variables.

- ANOVA and the assessment of the effect of educational organizations' categories on the accessibility of educational organizations in Russia's regions to the disabled people.

The first step of building the correlation matrix is Microsoft Excel-based. Based on the "Table I" data, we get the following correlation matrix "Table II".

Based on the correlation matrix calculations "Table II" and given Cheddock scale for the correlation estimate, the following conclusions were made [1]:

- The relation between the accessibility of secondary professional education organizations in the culture sector and that of children's art schools in Russian regions should be interpreted as direct and high;

- The relation between the accessibility of high education in the cultural sector (regional and municipal universities) and that of the secondary professional establishments in the same sector in Russian regions should be interpreted as direct and weak;

- The relation between the accessibility of high education in the cultural sector (regional and municipal universities) and that of the children's art schools in the same sector in Russian regions should be interpreted as direct and weak.

Particular interest for the research, obviously, focuses on the most correlative relationshipon between the accessibility of secondary professional education in the cultural sector in Russia's regions and the accessibility of children's art schools in the cultural sector in Russia's regions, expressed by the correlation coefficient 0.71 . Meantime, subsequently other distinguished relations will be studied as well.

The second step envisages the construction of regressions and the identification of mathematical expressions, which are a descriptor of the variables' relationship. 

FEDERATION

\begin{tabular}{|c|l|l|l|}
\hline & $\begin{array}{c}\text { Accessibility of high education in } \\
\text { cultural sector (regional and municipal } \\
\text { universities) in Russian regions }\end{array}$ & $\begin{array}{c}\text { Accessibility of secondary } \\
\text { professional education in cultural } \\
\text { sector in Russian regions }\end{array}$ & $\begin{array}{c}\text { Accessibility of children's } \\
\text { art schools in cultural } \\
\text { sector in Russian regions }\end{array}$ \\
\hline $\begin{array}{c}\text { Accessibility of high education in cultural } \\
\text { sector (regional and municipal } \\
\text { universities) in Russian regions }\end{array}$ & 1 & 1 & \\
\hline $\begin{array}{c}\text { Accessibility of secondary professional } \\
\text { education in cultural sector in Russian } \\
\text { regions }\end{array}$ & 0.28 & 0.71 & 1 \\
\hline $\begin{array}{c}\text { Accessibility of children's art schools in } \\
\text { culture in the RF territorial entities }\end{array}$ & 0.28 & & \\
\hline
\end{tabular}

Let us present initially the regression which reflects the approximant of the ratio of secondary professional organizations' accessibility in the cultural sector in Russia's regions to the children's art schools' accessibility "Fig. 1".

"Fig. 1" demonstrates the line of regression, highlighting the character of interrelatedness of the accessibility of secondary professional organizations and of children's art schools in the cultural sector in Russian regions. In addition, the function (equation) approximating the regression line is being defined (1):

$$
y=-0.1533 \times 3+1.7472 x 2+8.8903 x+24.066
$$

The computed function is polynomial and is described by the reliability of $\mathrm{R} 2=0.5091$ approximation value. The function allows calculation of the values of two-way relation, namely, of the extent to which the secondary professional education organizations' accessibility in the cultural sector varies under the corresponding change in the accessibility of children's art schools.

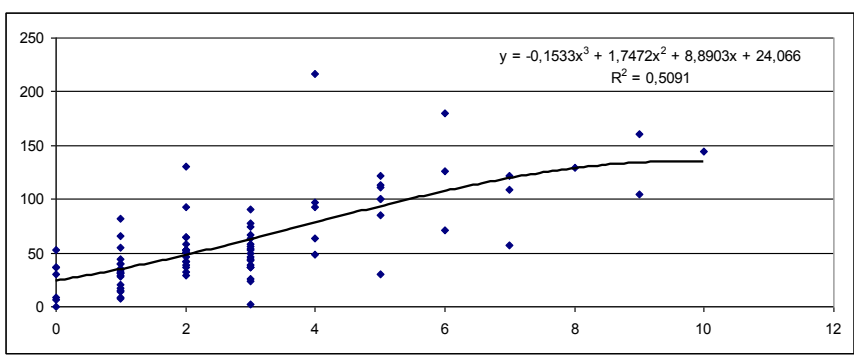

Fig. 1. Regression of the balance between the accessibility of secondary professional organizations and of children's art schools in cultural sector in Russian regions.

Let us calculate the regression approximating the dependency function for the accessibility of secondary professional education organizations and of children's art schools in the cultural sector in Russian regions "Fig. 2".

"Fig. 2" depicts the line of regression identifying the character of interrelation between the accessibility of high education (regional and municipal universities) and of the secondary professional education in Russian region's cultural sector. This regression line is approximated by the following function (equation) (2):

$$
y=-0.4782 x^{2}+1.8512 x+2.4603
$$

The computed function is polynomial and is described by the reliability of $\mathrm{R} 2=0.0845$ approximation value. It allows calculating the values of two-way relation-to what extent the accessibility of high education organizations in the cultural sector is subject to modification under appropriate changes in the secondary professional organizations' accessibility in the cultural sector of Russian regions.

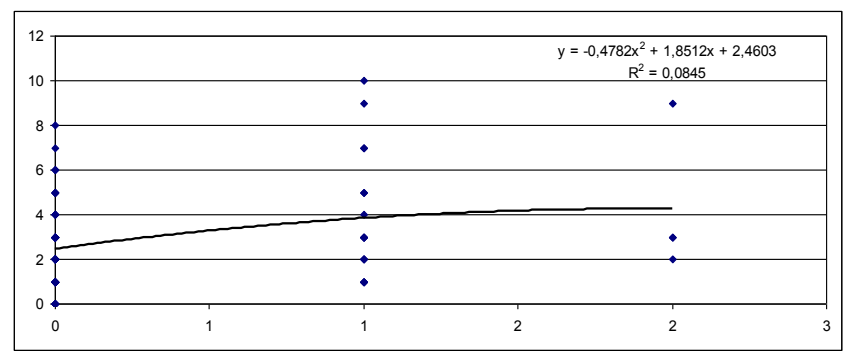

Fig. 2. Regression of the balance between the accessibility of higher education in the cultural sector (regional and municipal universities) and of secondary professional organizations the cultural sector of Russian regions.

Let us calculate the third regression, approximating the balance between the accessibility of high education in the cultural sector (regional and municipal universities) and of children's art schools in Russian regions' cultural sector "Fig. 3".

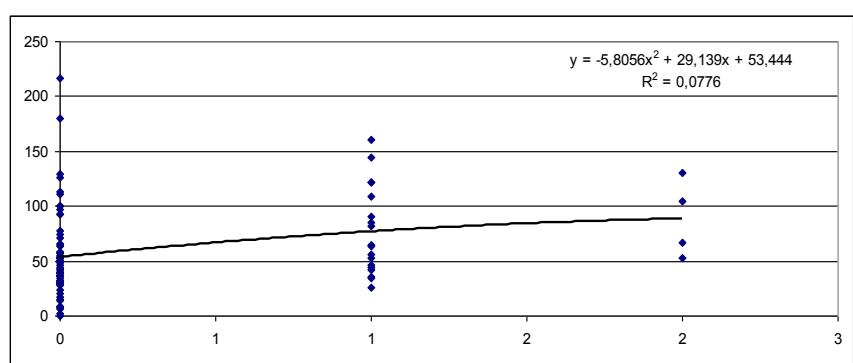

Fig. 3. Regression of the balance between the accessibility of high education (regional and municipal universities) in cultural sector and of children's art schools in Russian regions.

"Fig. 3" presents the line of regression identifying the nature of relationship between the accessibility of high education (regional and municipal universities) and children's art schools in the culture sector in the regions of the Russian Federation. This regression line is approximated by the following function (equation) (3): 


$$
y=-5.8056 x^{2}+29.139 x+53.444
$$

The computed function is polynomial and features the reliability of $\mathrm{R} 2=0.0776$ approximation value. The received function allows calculating two-way relation values, namely, how far the accessibility of high education (regional and municipal universities) in the cultural sector is subject to modification under corresponding changes in the accessibility of children's art schools in the cultural sector of Russian regions.

As provided for by the third step of the research, the one-way analysis of variance (ANOVA) and assessment of the effect of educational organizations' categories on the accessibility to the disabled persons of educational organizations in the Russian regions is carried out. Let us find out whether there are discrepancies in the different categories of educational organizations' accessibility and how these different categories affect the accessibility to the people with disabilities and with special needs of educational organizations in Russia's regions.

According to the formulated main hypothesis, all average values from different aggregates $\mathbf{k}$ (the accessibility of higher education (regional and municipal universities) in the cultural sector in Russian regions, the accessibility of secondary professional organizations in the cultural sector in Russian regions, the accessibility of children's art schools in the cultural sector in Russian regions) are equal.

$$
\mathrm{H}_{0:} \mu_{1} \neq \mu_{\mathrm{k}} \text { (all equal), (or } X_{1}=X_{2}=\ldots=X_{k} \text {. }
$$

The alternative hypothesis states that a minimum of any two mean values are not equal.

$$
\mathrm{H}_{1}: \mu_{1} \neq \mu_{\mathrm{k}} \text { (a minimum two are not equal), (or } X_{l} \neq X_{k} \text { ). }
$$

For calculations, we will use the Microsoft Excel tool. The calculation data is provided in "Table III".

\section{TABLE III. ONE-WAY ANALYSIS OF VARIANCE (ANOVA) OF THE ACCESSIBILITY TO THE DISABLED PEOPLE OF EDUCATIONAL}

\begin{tabular}{|c|c|c|c|c|c|c|}
\hline Source of variation & $S S$ & $d f$ & $M S$ & $F$ & P-Value & $F$ Critical \\
\hline Between groups & 193965.4824 & 2 & 96982.74118 & 171.6187643 & $9.24 \mathrm{E}-48$ & 3.031628943 \\
\hline Inside groups & 142406.6353 & 252 & 565.1056956 & & & \\
\hline Total & 336372.1176 & 254 & & & & \\
\hline
\end{tabular}
ORGANIZATIONS IN THE REGIONS OF THE RUSSIAN FEDERATION

\begin{tabular}{lcccc}
\hline \multicolumn{1}{c}{ Groups } & Score & Total & Average & Varicnce \\
Column 1 & 85 & 26 & 0.305882353 & 0.310084034 \\
Column 2 & 85 & 241 & 2.835294118 & 4.901120448 \\
Column 3 & 85 & 5103 & 60.03529412 & 1690.105882 \\
\hline
\end{tabular}

The carried out calculations point to a significant difference in the accessibility of different categories of educational organizations, implied by the ratio $\mathrm{F}>\mathrm{F}_{\text {critical }}$ $(171.6187643>3.031628943)$ and the unlikely acceptance of the null hypothesis (P-value $=9.24 \mathrm{E}-48$, which is less than 0.05$)$, i. e. the null hypothesis $\left(\mathrm{H}_{0}\right)$ may be rejected while an alternative hypothesis $\left(\mathrm{H}_{1}\right)$ is adopted.
In this regard, the fact that the accessibility of different categories of educational organizations significantly varies has been proved. Therefore, it is especially important to assess the effect of various categories of educational organizations on their accessibility to the disabled people in Russian regions. To estimate this effect the correlation ratio $\eta^{2}$ (eta squared) is applied; $\eta^{2}$ (eta squared) is calculated as a ratio of between-group variation (SS between groups) to the total variance (SS total). Following the corresponding division, we receive the value of the force of factorial effect $-\eta^{2}=0.576639597$ ( $\sim 0.58$ or $58 \%$ in percentage terms).

Therefore, it can be concluded that the accessibility to the people with disabilities and with special needs of educational organizations in Russian regions is $58 \%$ dependent on the accessibility of various categories $(\mathrm{k})$ of such educational organizations. The remaining $42 \%$ of the accessibility to the disabled people of educational organizations in Russian regions is bound to other variables (factors), the analysis of which is beyond the scope of this study.

\section{CONCLUSION}

It can be ascertained from the above that the hypothesis put forward has been confirmed. Findings of the correlationregressive and ANOVA analyses of the accessibility to the people with disabilities and with special needs of educational organizations in the regions of the Russian Federation verify that the use of specified techniques of statistical analysis allows revealing the trends and assessing the availability of multi-level education for the disabled people. Aassessment of the multi-level education's availability for the people with disabilities and with special needs in the regions of the Russian Federation depends upon the accessibility of the educational organizations' different categories. This dependency relation is most pronounced for the secondary professional education organizations and children's art schools in the cultural sector in Russian regions. The research findings provide theoretical and methodological basis for addressing current theoretical and practical problems of applying the methods of assessment and analysis of educational organizations' accessibility in Russia's regions to the people with disabilities and special needs. Also, the findings contribute to the development of theoretical bases for the creation and introduction of the most innovative procedure for the study of educational organizations' accessibility to the people with disabilities and with special needs.

\section{REFERENCES}

[1] V.R. Baraz, Regression analysis of business practice rates correlation using Excel tool: tutorial, Ekaterinburg: GOU VPO "UGTU-UPI", 2005, p. 102.

[2] Department director Grigory Lekarev in his interview with internet resource Miloserdie.ru spoke about the development of accessibility for the disabled people, http://www.rosmintrud.ru/social/invaliddefence/250.

[3] I.I. Yeliseeva, M.M. Yuzbashev, General Theory of Statistics: Textbook / Editor I.I. Yeliseeva, $4^{\text {th }}$ revised edition, M.: Finansy i Statistika, 2002, p. 480. 
[4] V.S. Lyalin, Statistics: Theory and practice in Excel, M.: Finansy i Statistika, INFRA-M, 2010, p. 448.

[5] On long-term regional special program "Accessibility" for the years 2011-2013 (as amended by December 3, 2013) (as amended by January 23, 2014) http://docs.cntd.ru/document/933015129.

[6] Note to the meeting of the general session of the Ministry of culture of the Russian Federation on the accessibility of cultural goods to the disabled mkrf.ru/upload/mkrf/mkdocs2015/02_11_2015_9.docx

people",

[7] Participants of the Cultural Forum discussed the problems of accessibility of cultural goods to the people with disabilities http://mkrf.ru/upload/mkrf/mkdocs2016/06_12_2016_01.7z

[8] Federal law "On Amendments to regulations of the Russian Federation concerning social protection of the disabled people in the context of ratification of the Convention on the Rights of Persons with Disabilities" No. 419-FZ as of 01.12.2014, http://www.consultant.ru/document/cons_doc_LAW_171577/ 